\title{
Rekomendasi Data Center Menggunakan Pendekatan Standarisasi TIA-942 di Puslitbang XYZ
}

\author{
Frans Fernando Asali ${ }^{1}$, Irawan Afrianto ${ }^{2}$ \\ 1,2 Program Studi Teknik Informatika, Universitas Komputer Indonesia (UNIKOM) \\ Jl. Dipatiukur 112-116 Bandung \\ ${ }^{1}$ fransfernandoasali@gmail.com, ${ }^{2}$ irawan.afrianto@email.unikom.ac.id
}

\begin{abstract}
Abstrak - Puslitbang XYZ adalah salah satu litbang yang memperhatikan penggunaan dan pemanfaatan teknologi informasi (TI). Puslitbang XYZ memiliki divisi IT dan resource yang diletakan pada suatu tempat yang disebut dengan data center. Data center Puslitbang XYZ saat ini memiliki ukuran luas computer room yang kecil, konstruksi ruang yang belum ideal, pelabelan dan dokumentasi yang belum baik, serta server yang kadang mengalami restart. Akibat dari kondisi tersebut membuat proses kegiatan penelitian Puslitbang XYZ menjadi terganggu. Berdasarkan masalah-masalah tersebut, maka untuk mengatasinya perlu dilakukan standarisasi data center, sehingga terbentuk kriteria data center yang baik, yaitu availability, scalability/flexibility dan security. Dalam melakukan penelitian menggunakan metode gap analysis sebagai acuan dan TIA-942 sebagai standar untuk perancangan data center. Adapun hasil dari penelitian ini, yaitu menghasilkan dokumentasi keseluruhan terhadap kondisi infrastruktur data center saat ini, menghasilkan perbandingan antara kondisi saat ini, kondisi desain terhadap kondisi TIA tier 1 dan menghasilkan desain/rancangan data center berdasarkan pendekatan TIA tier 1.
\end{abstract}

Kata Kunci-Data Center, Jaringan, Server, TIA-942, Gap Analysis, Rekomendasi, Puslitbang XYZ

\section{PENDAHULUAN}

Data center merupakan fasilitas yang digunakan untuk penempatan beberapa kumpulan server atau sistem komputer dan sistem penyimpanan data (storage) yang dikondisikan dengan pengaturan catu daya, pengatur udara, pencegah bahaya kebakaran dan biasanya dilengkapi pula dengan sistem pengamanan fisik. [2]

Puslitbang XYZ merupakan salah satu instansi yang berada di bawah Badan Litbang Departemen Pekerjaan Umum. memiliki sejumlah server yang disimpan di ruang server atau lebih dikenal dengan data center. Data center Puslitbang XYZ akan terus berkembang seiring dengan banyaknya pekerjaan/penelitian yang dilakukan. Adapun keadaan data center saat ini memiliki ukuran computer room yang kecil dengan penempatan maksimum empat kabinet, server yang kadang suka mengalami restart, kesulitan dalam melakukan trobleshooting karena belum terdokumentasinya pelabelan yang baik, serta konstruksi ruang yang belum ideal dan aman. Akibat dari keadaan ini membuat proses kegiatan penelitian Puslitbang XYZ menjadi terganggu, tidak dapat dilakukannya penambahan kabinet, lamanya dalam melakukan trobleshooting serta rawan terhadap tingkat kejahatan karena banyaknya penggunaan jendela.

Untuk mengatasinya maka perlu dilakukan standarisasi data center agar terbentuknya kriteria data center yang baik yaitu availability, scalability/flexibility dan security. Salah satu standar internasional yang mengatur tentang data center yaitu TIA-942. Standar ini disetujui oleh Telecommunications Industry Association (TIA) Komite bagian TR 42.2, TIA Komite Insinyur Teknis TR 42 dan Institut Standar Nasional Amerika (ANSI) dan lebih dari 60 organisasi dalam industry telekomunikasi berkontribusi untuk perkembangan standard ini termasuk manufaktur, konsultan, pengguna akhir, dan organisasi lainnya.[2]

Perancangan data center berangkat dari kebutuhan yang ada, untuk kemudian didefinisikan berbagai perlengkapan IT yang diperlukan beserta pemilihan teknologi berbarengan dengan perencanaan infrastruktur data center yang lain. Ada 4 tier dalam perancangan data center yang setiap tier nya menawarkan tingkat availabilitas yang berbeda disesuaikan dengan kebutuhan suatu data center. Menurut TIA (Telecommunication Industry Association), adapun aspek penilaian tier pada data center dapat dikelompokan menjadi 4 kriteria yaitu aspek arsitektur bangunan, aspek kelistrikan, aspek telekomunikasi dan aspek mekanik. [1]

Data center merupakan gabungan dari infrastruktur jaringan komputer, perangkat kelistrikan pendukung serta inftrastruktur bangunan yang memadai guna majemen dan monitoring data dengan baik. [5]

Dalam melakukan analisis dan perancangan, peneliti menggunakan metode standar Gap Analysis. Gap analysis merupakan metode perbandingan yang digunakan untuk mencari kesenjangan antara kondisi saat ini terhadap kondisi yang ingin dicapai. Oleh karena itu dengan menggunakan metode gap analysis maka dapat mempermudah peneliti untuk menentukan langkah-langkah pengerjaan dalam mencapai tujuan penelitian serta terbentuknya proses tahapan penelitian yang lebih terstruktur [6].

Berdasarkan hal tersebut, maka peneliti berharap dapat mengembangkan suatu rancangan 
data center yang memenuhi kriteria data center yang baik serta sesuai dengan standar TIA guna dapat memberikan rekomendasi/solusi data center bagi pihak Puslitbang XYZ.

\section{METODOLOGI PENELITIAN}

Metodologi yang digunakan dalam penelitian ini dibagi menjadi menjadi beberapa langkah kegiatan dimana hal tersebut dilakukan guna kemudahan serta menfokuskan capaian yang akan diperoleh [4].

Dalam implementasi metodologi penelitian yang dikembangkan, beberapa metode dasar seperti studi literatur, wawancara, observasi, gap analysis dan metode TIA Tierl digunakan sebagai alat bantu dalam pencapaian hasil peneltian yang diinginkan.

Adapun tahapan yang dilakukan adalah melakukan identifikasi terhadap kondisi infrastruktur data center saat ini, melakukan perbandingan antara kondisi saat ini dan kondisi desain terhadap kondisi TIA tier 1, serta memberikan rekomendasi dan rancangan desain data center Puslitbang XYZ berdasarkan pendekatan TIA tier 1.

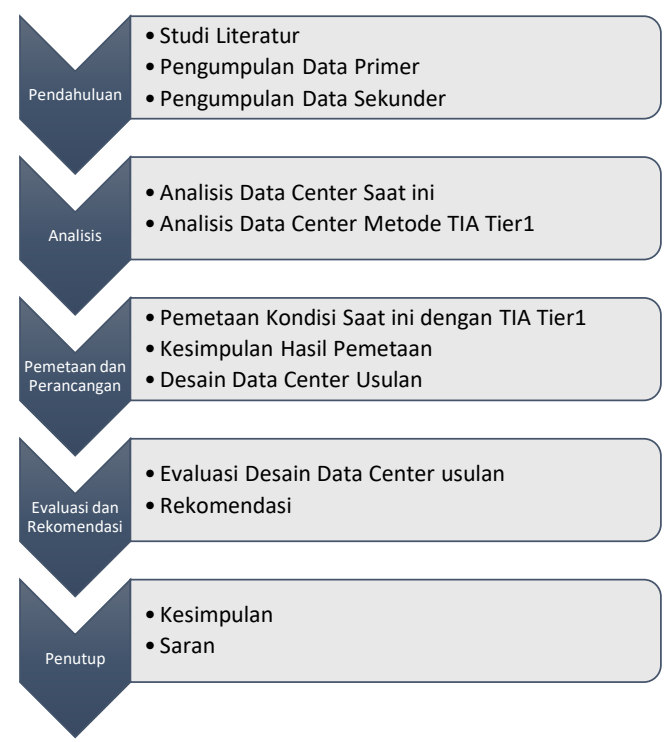

Gambar 1 Metodologi Penelitian

\section{DATA DAN ANALISIS PENELITIAN}

\section{A. Dokumentasi Data Center Saat Ini}

Data center Puslitbang XYZ terletak di lantai 4 gedung utama Puslitbang XYZ, dengan ukuran panjang, lebar dan tinggi yaitu 7,7 x 5,5 x 2,5 meter. Sebagian ruangan dengan luas sekitar 1,7 x 5,5 meter disekat untuk dijadikan computer room, pada ruang ini ditempatkan empat unit kabinet dan satu unit rak distribusi.

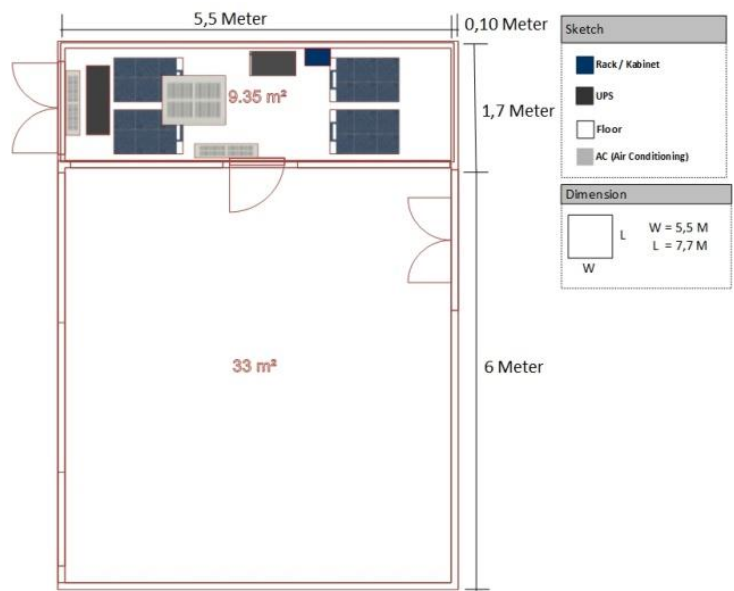

Gambar 2 Denah Ruang Data Center

Struktur lantai pada computer room belum menggunakan sistem raised floor serta struktur pembentuk bangunan seperti partisi, plafon serta pintu masih menggunakan bahan yang mudah terbakar/tidak tahan api. Kapasitas beban lantai tidak terstandarisasi sesuai standar TIA. Banyaknya jendela kaca dan dinding pada computer room yang terdapat celah untuk jalur pengkabelan membuat debu mudah masuk serta dapat meningkatkan penyerapan panas matahari dan mengurangi keamanan dalam data center. [7]

Kemudian pada sistem pendinginan yang diterapkan didalam computer room menggunakan air conditioning (AC) split sebanyak 3 perangkat pendinginan. Dari ketiga perangkat pendingin, yang aktif hanya satu yaitu AC merek daikin berukuran 2 pk dan berjalan tidak normal atau tidak optimal dalam melakukan pendinginan. Selain itu juga terdapat dua unit UPS ukuran $10000 \mathrm{~V}$ dan $3000 \mathrm{~V}$ serta satu unit generator berbahan bakar gas. Pengaktifan generator masih dilakukan secara manual walaupun telah memiliki ATS, serta penempatan generator ini belum ditempatkan/di instalasi secara permanen.

Sementara itu pada sistem kelistrikan Puslitbang XYZ terdiri dari 3 phase 1 netral. Dari 3 phase dan 1 netral tersebut yang digunakan hanya 2 phase yaitu untuk office dan data center. Sedangkan kondisi untuk sistem pengkabelan telekomunikasi masih belum rapih dan tidak terdokumentasi dengan baik. Pada bagian kabel UTP dan coaxial belum menggunakan patch panel, sementara pada bagian fiber optic sudah terimplementasi dengan baik yaitu telah menggunakan patch panel.

Untuk sistem proteksi kebakaran data center Puslitbang XYZ hanya menyediakan alat pemadam kebakaran portable yang terletak diluar ruangan data center. Sedangkan untuk sistem keamanan fisik data center masih dibilang belum diperhatikan yaitu terlihat data center hanya memiliki kunci di support room dan computer room sedangkan beberapa 
kabinet tidak terkunci, belum dilengkapi dengan $\log$ book bagi siapapun yang mengakses data center, belum menggunakan kamera pengawas cctv dan access door.

Adapun untuk kabinet yang digunakan merupakan merek fortuna 19" ukuran 45RU dengan panjang, lebar dan tinggi adalah $1,10 \times 0.60 \times 2,17$ meter. Setelah melakukan pendokumentasian terhadap spesifikasi kabinet maka dilakukan penggambaran untuk posisi server di dalamnya [9]. Sebagai contoh untuk penggambaran kabinet ke-4 dapat dilihat pada gambar 3 .

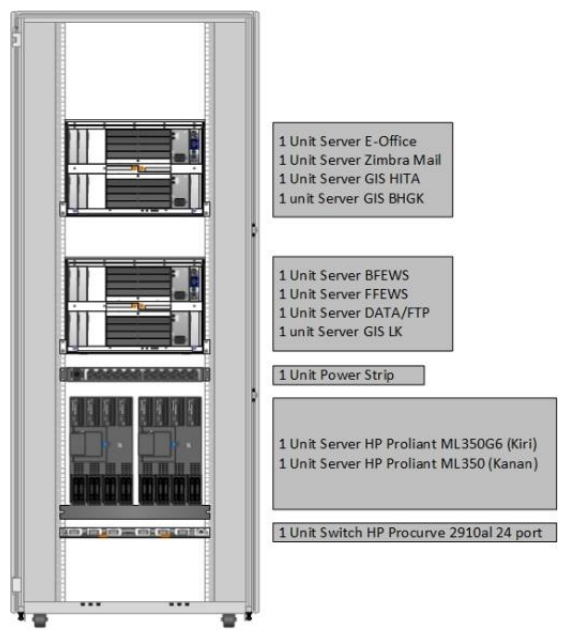

Gambar 3 Susunan Perangkat di Kabinet-4

Gambar 4 menunjukkan topologi jaringan pada data center saat ini yakni sebagai berikut:

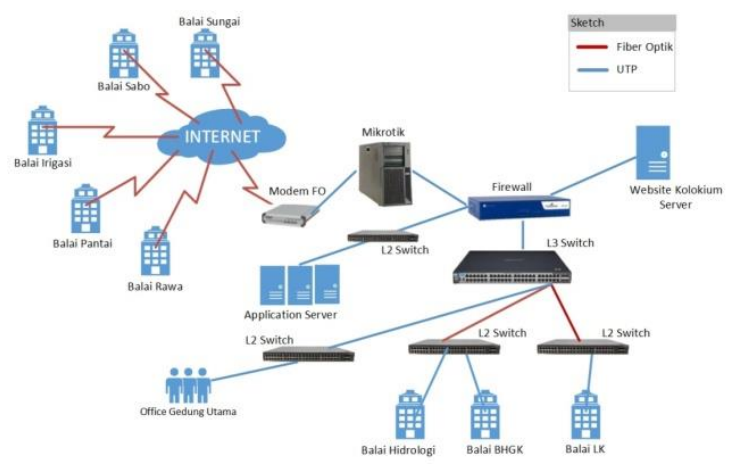

Gambar 4 Topologi Jaringan Eksisting Puslitbang $\mathrm{XYZ}$

Pada gambar 4 terlihat bahwa keterhubungan jaringan data center digedung utama Puslitbang XYZ dengan lima balai yang berada diluar kota bandung serta tiga balai yang berada disatu lingkungan Puslitbang XYZ yaitu balai hidrologi, LK dan BHGK yang menggunakan media koneksi kabel fiber optic. Jaringan intranet data center Puslitbang XYZ, bermula dari modem FO yang dihubungkan kemikrotik. Mikrotik disini hanya berfungsi sebagai gateway sedangkan manajemen bandwidth dan pengaturan jaringan dilakukan oleh device firewall. Di firewall terdapat 4 port yang terhubung dengan mikrotik, server website kolokium, switch layer 2 dan switch layer 3. Pada switch layer 2 dikoneksikan untuk server-server aplikasi, sedangkan switch layer 3 dikoneksikan ditiga switch layer 2 untuk balai-balai yang berada disekitar lingkungan Puslitbang XYZ dan keswitch layer 2 berikutnya untuk gedung office.

\section{B. Analisis Metode TIA Tier 1}

Analisis metode TIA tier 1 merupakan analisis yang mengacu kepada kebutuhan tier 1 yang dibutuhkan data center. Adapun kriteria dalam menentukannya terdiri dari empat aspek penilaian yaitu arsitektur bangunan, telekomunikasi, mekanik dan listrik.

Dalam penerapannya standar TIA Tier 1 mewajibkan setiap aspek penilian memiliki kriterikriteria wajib yang harus terpenuhi seperti ppada tabel 1 dan tabel 2.

Tabel 11 Aspek Penilai Data Center TIA Tier 1

\begin{tabular}{|l|c|}
\hline Aspek Penilaian & Kriteria Wajib Terpenuhi \\
\hline Arsitektur & 2 \\
\hline Kelistrikan & 15 \\
\hline Telekomunikasi & 2 \\
\hline Mekanik & 3 \\
\hline
\end{tabular}

Tabel 22 Arsitektur Telekomunikasi Tier 1

\begin{tabular}{|l|c|}
\hline Kebutuhan & Tier1 \\
\hline General & ya \\
\hline $\begin{array}{l}\text { Sistem pengkabelan, rack, kabinet } \\
\text { dan jalur pengkabelan memenuhi } \\
\text { spesifikasi TIA }\end{array}$ & \\
\hline $\begin{array}{l}\text { Patch panel, outlets dan sistem } \\
\text { pengkabelan untuk dilabeli } \\
\text { mengikuti ANSI/TIA/EIA-606-A } \\
\text { and annex B distandar TIA. Rack } \\
\text { dan kabinet untuk dilabeli didepan } \\
\text { dan belakang }\end{array}$ \\
\hline
\end{tabular}

\section{Pemetaan Kondisi Saat Ini dengan TIA Tier 1}

Guna mengetahui dan mendapatkan informasi sejauh mana kondisi saat ini terpenuhi terhadap kondisi TIA tier 1 maka dilakukan pemetaan. Cara melakukan pemetaan yaitu dengan membandingkan kondisi standar terhadap kondisi saat ini. Dari hasil wawancara yang telah dilakukan sebelumnya. Pada tabel aspek tier terdapat dua kondisi penilaian yaitu wajib, diijinkan dan tidak wajib. Dari dua kondisi tersebut maka kondisi wajib sajalah yang akan dinilai pada tahap pemappingan, hal ini sesuai dengan standar TIA yang menyebutkan bahwa untuk melakukan standarisasi tier maka 
kriteria wajib pada setiap aspek semuanya harus terpenuhi.

Adapun hasil pemetaan yang telah dilakukan terhadap 4 aspek penilaian tier 1, maka didapat hasil dari pemetaaan yang terlihat pada Tabel 3.

Tabel 3. Hasil Pemetaan Tier 1 dengan Kondisi Saat ini

\begin{tabular}{|l|c|c|}
\hline $\begin{array}{l}\text { Aspek } \\
\text { Penilaian }\end{array}$ & $\begin{array}{c}\text { Jumlah } \\
\text { kriteria wajib }\end{array}$ & $\begin{array}{c}\text { Jumlah kriteria } \\
\text { terpenuhi }\end{array}$ \\
\hline Arsitektur & 2 & 0 \\
\hline Kelistrikan & 15 & 10 \\
\hline Telekomunikasi & 2 & 0 \\
\hline Mekanik & 3 & 0 \\
\hline Total & $\mathbf{2 2}$ & $\mathbf{1 0}$ \\
\hline
\end{tabular}

Pada tabel 3 terlihat bawah total kriteria terpenuhi adalah 10 kriteria dari 22 kritieria wajib dan masih ada 12 kriteria yang harus dicapai. Oleh karena itu dapat disimpulkan bahwa data center saat ini belum mencapai tier 1 . Sementara itu untuk mencapai tier 2, tier 3 dan tier 4 belum dapat dilakukan karena keterbatasan luas ruang eksisting yang tidak sebanding dengan banyaknya peralatan infrastruktur yang disyaratkan pada tier tersebut. Maka dari itu tahap desain data center pada penelitian ini merupakan desain untuk mencapai tier 1.

\section{PERANCANGAN DAN REKOMENDASI}

\section{A. Desain Data Center Usulan}

Dalam melakukan desain data center usulan mengikuti pendekatan standar TIA yang mengacu ke standar yang lebih spesifik seperti yang terlihat pada gambar 5 .

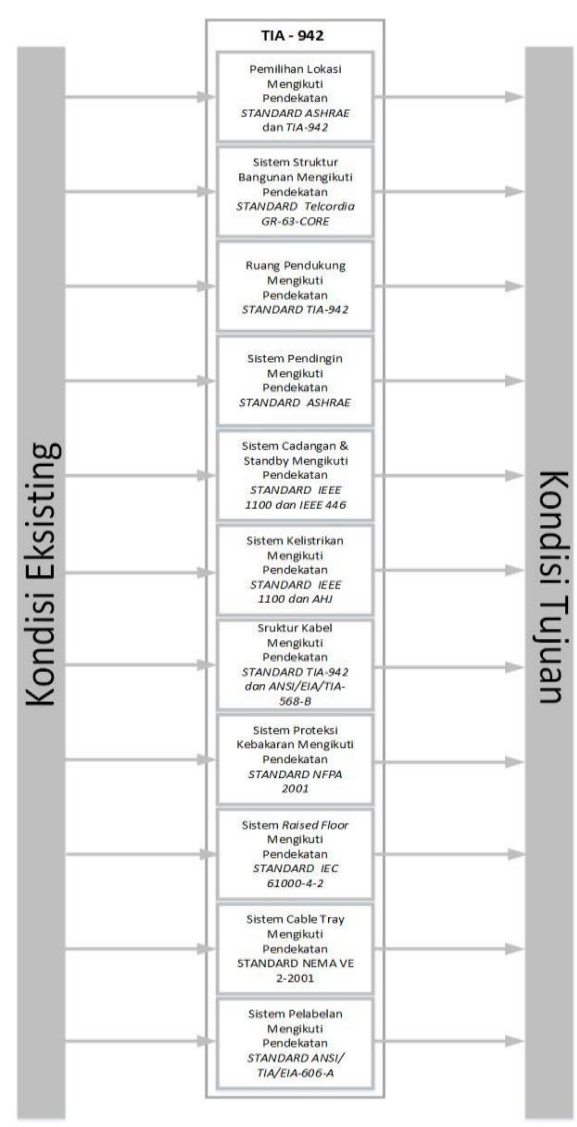

Gambar 5 Proses Desain Komponen Data Center Usulan

Dalam melakukan perancangan data center usulan, terdapat aliran proses seperti yang ditunjukkan pada gambar 6 dimana lima aliran utama, yang tiga diantaranya memiliki sistem pendukung, yaitu evaluasi infrastruktur bangunan, desain ruangan computer room dan pengaturan peralatan.

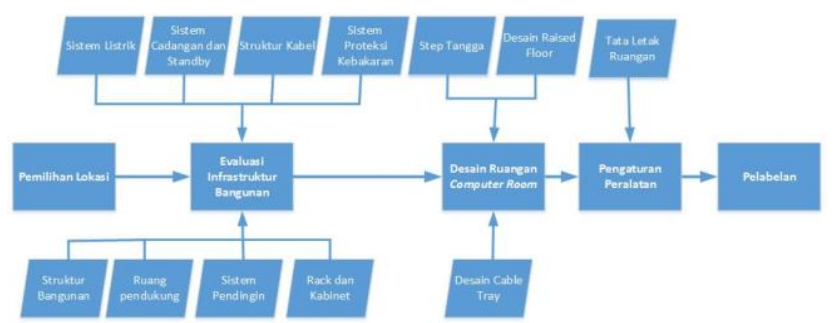

Gambar 6 Proses Perancangan Data Center

\section{A.1 Pemilihan Lokasi}

Hal pertama yang harus dilakukan untuk membangun data center yaitu pemilihan lokasi. Untuk lokasi desain data center usulan masih menggunakan tempat yang sama dikarenakan terbatasnya tempat pada gedung utama Puslitbang XYZ dan belum ada perencanaan dari pihak 
Puslitbang XYZ untuk pindah atau menggunakan gedung lain/baru.

\section{A.2 Evaluasi Infrastruktur Bangunan}

Evaluasi infrastruktur bangunan seperti yang terlihat pada gambar 6 terdiri dari sistem pendukung, yakni struktur bangunan, ruang pendukung, sistem pendingin, rack dan kabinet, sistem listrik, sistem cadangan dan standby, struktur kabel dan sistem proteksi kebakaran. Adapun penjelasan mengenai sistem-sistem tersebut adalah sebagai berikut:

Berdasarkan wawancara yang peneliti lakukan dengan pihak IT Puslitbang XYZ, hasil yang dapat peneliti simpulkan dari wawancara tersebut adalah pada struktur bangunan seperti beban lantai, penambahan tinggi plafon dan penggunaan banyak lapis dinding belum bisa diimplementasikan karena gedung tempat data center berada merupakan gedung yang menyatu dengan struktur bangunan office. Oleh karena itu untuk ketentuan struktur bangunan akan dijelaskan dibab 4 pada bagian rekomendasi.

Pada data center usulan memiliki ruang pendukung yang dibutuhkan yaitu electrical \& mechanical room, storage room \& loading dock, operation center dan computer room. Pada data center usulan memiliki ruang pendukung yang dibutuhkan yaitu electrical \& mechanical room, storage room \& loading dock, operation center dan computer room.

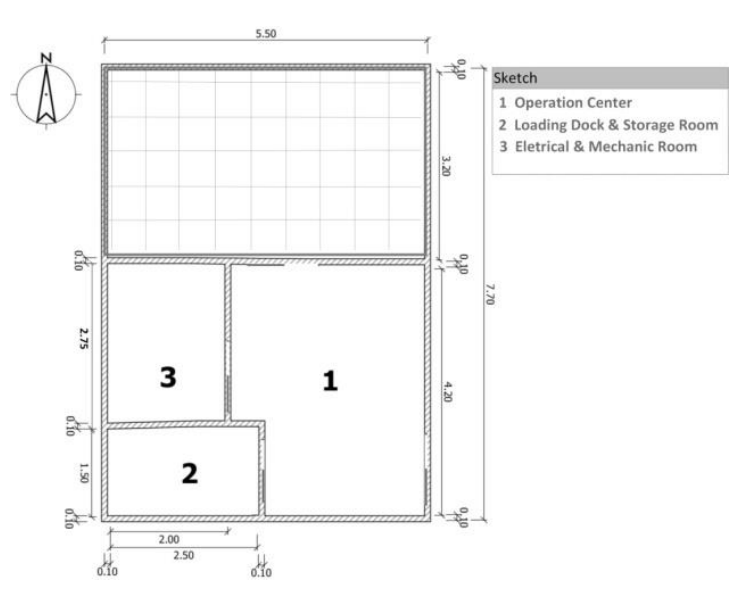

Gambar 7 Denah Ruang Pendukung

Sistem pendingin yang diusulkan, menggunakan HVAC DX dengan ketentuan temperature udara yang harus dijaga sesuai aturan yang ditetapkan. Sedangkan untuk metode pendistribusian udara keperalatan telekomunikasi data center menggunakan metode Row Oriented Cooling System. Adapun cara kerjanya dapat dilihat pada Gambar 8.

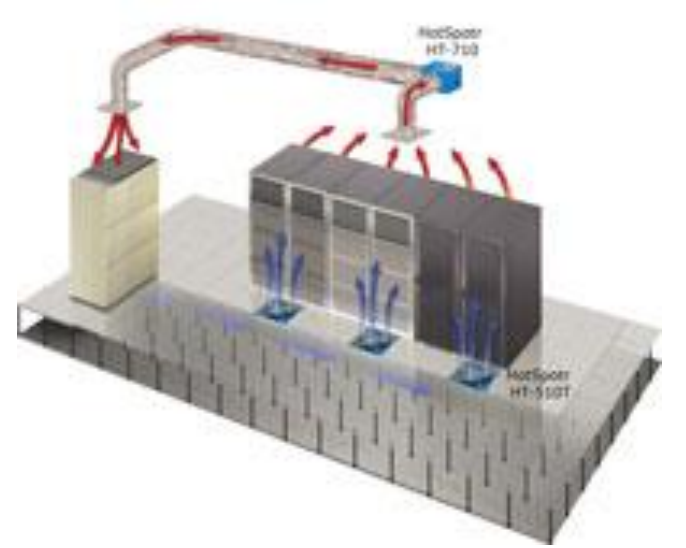

Gambar 8 Cara Kerja HVAC Dengan Exhaust Fan

Peletakan perangkat HVAC / CRAC (computer room air conditioning) didalam computer room akan disejajarkan dengan perforated tile pada cold aisles. Berikut merupakan denah penggambaran dari perangkat pendingin dan aliran udara didalam computer room.[2]

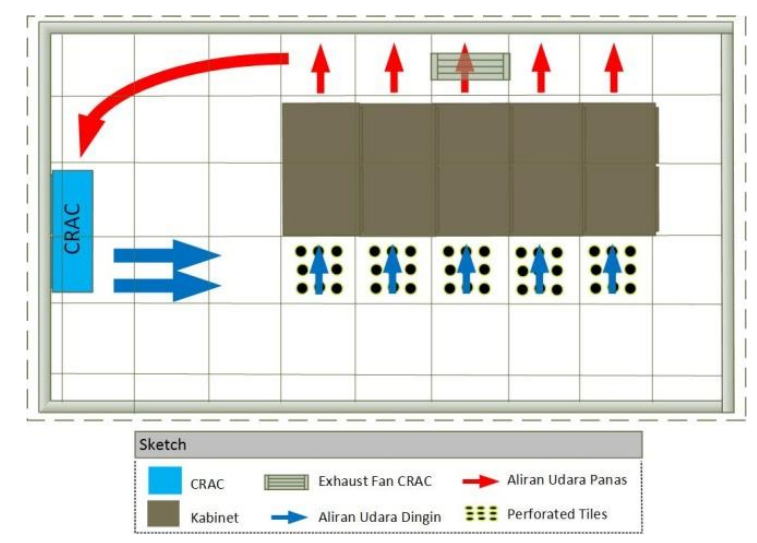

Gambar 9 Denah Perangkat Pendinginan dan Aliran Udara

Sementara itu pada rack dan kabinet harus memiliki ketentuan spesifikasi sebagai berikut yaitu Ukuran tinggi tidak lebih dari 2,40 m, lebar 0,60 m dan kedalaman $1,10 \mathrm{~m}$, Rel bagian depan/belakang tersembunyi minimal $100 \mathrm{~mm}$, Berukuran minimal 42RU, Memiliki ventilasi yang cukup untuk peralatan didalamnya, Memiliki features sistem grounding dan vertical cable manager. Setiap kabinet yang terpasang harus memiliki area untuk pengaksesan atau disebut dengan clearance area [8] [9]. Adapun clearance area yang akan diterapkan untuk bagian belakang kabinet adalah 0,60 m dan untuk bagian depan kabinet 1,00 m. Dalam penempatan kabinet di raised floor, kabinet harus dikuatkan dengan baut mur untuk mencegah terjadinya guncangan akibat gempat serta bagian depan kabinet harus menyesuaikan dengan baris cold aisles agar peralatan didalam kabinet dapat menghisap udara dingin yang keluar dari perforated 
tiles dan tidak mengganggu dalam pengangkatan ubin depan dan belakang dari kabinet.

Komponen untuk kebutuhan sistem listrik didukung oleh sistem cadangan dan standby yaitu terdiri dari UPS, generator, battery backup dan ATS. Sedangkan untuk pendistribusiannya menggunakan metode panel board distribution yang terdiri dari UPB dan panel circuit. Berikut denah dari perancangan sistem listrik pada data center usulan yang terlihat pada gambar 10 .

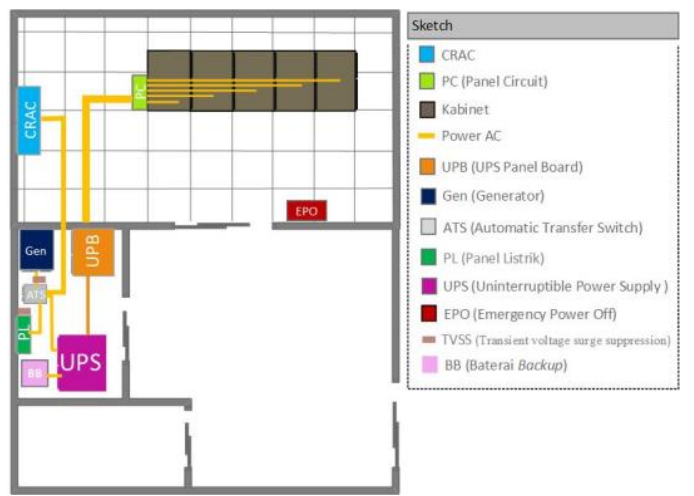

Gambar 10 Denah Sistem Kelistrikan

Sedangkan untuk perancangan sistem pengkabelan mengikuti topologi reduced data center topology dan mengimplementasikan sistem pengkabelan yang terstruktur. Adapun komponenkomponenya terdiri dari EDA, MDA dan patch panel. Adapun denah untuk sistem pengkabelan data center usulan dapat dilihat pada gambar 11 .

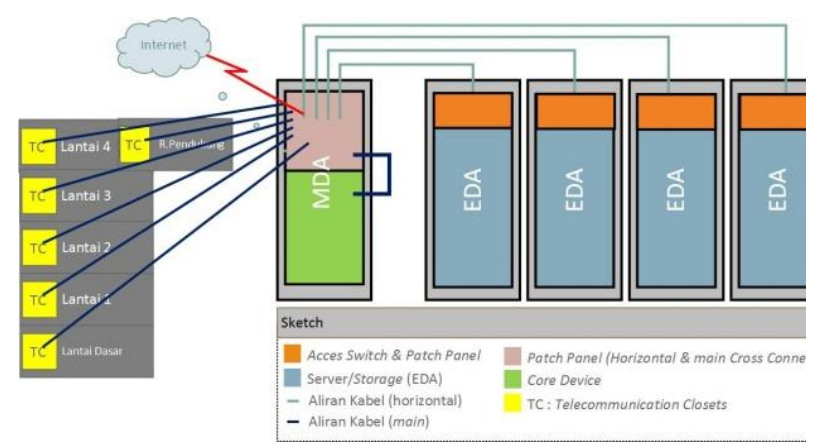

Gambar 11 Denah Struktur Pengkabelan

Beralih pada perancangan sistem proteksi kebakaran. Pada perancangan sistem proteksi kebakaran menggunakan sistem proteksi otomatis FM-200 seperti yang terlihat pada gambar 12 . Komponen pada sistem ini terdiri dari tabung fm200, fenwall control unit, discharge nozzle, fenwall detector,dicharge piping, fenwall detector piping. Kemudian peletakannya diposisikan menjadi 2 jenis yaitu under floor dan over head.

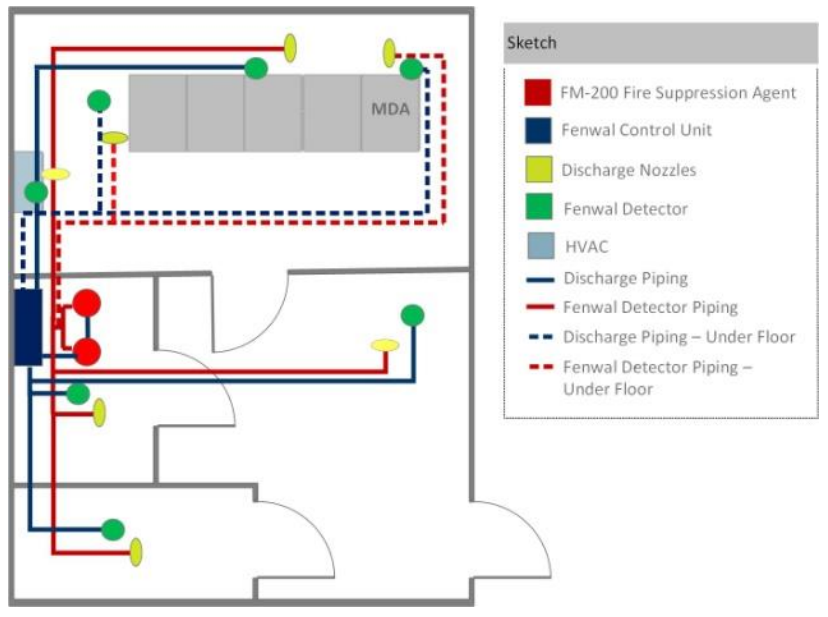

Gambar 12 Denah Letak Nozzle dan Fenwall Detector

\section{A.3 Desain Computer Room}

Pada aliran utama ini memiliki sistem pendukung yang terdiri dari step tangga, desain raised floor dan desain cable tray. Adapun perancangan dari sistem-sistem tersebut adalah sebagai berikut:

Untuk perancangan raised floor memiliki ketentuan sebagai berikut raised floor memiliki pedestal tiang penyangga berbahan galvanis dengan tinggi $35 \mathrm{~cm}$, menggunakan bolted stringer understructure (frame penyangga) berbahan galvanis serta dilengkapi oleh screws sebagai sekrup untuk pengunci dan panelnya memiliki ukuran panjang, lebar dan tinggi yaitu $60 \times 60 \times 3,5 \mathrm{~cm}$ yang berbahan Calcium Sulphate Panel Raised Floor yang telah dilapisi bahan vinyl anti statis atau lebih dikenal dengan nama raised floor tipe HPL (High Pressure Laminated) [7].

Setelah memilih raised floor yang sesuai kriteria TIA, maka yang harus diperhatikan adalah ketentuan pemotongan lantai ubin. Pemotongan lantai ubin untuk vertical cabling pada kabinet harus ditempatkan dibawah kabinet atau lokasi lain agar terhindar dari bahaya tersandung dan dipasangi peredam grommet untuk meminimalkan hilangnya udara dingin melalui lubang diubin lantai. Dari penjelasan sebelumnya mengenai spesifikasi dan pemotongan lantai ubin raised floor maka dibuat denah pemasangan raised floor pada computer room sebagai berikut: 


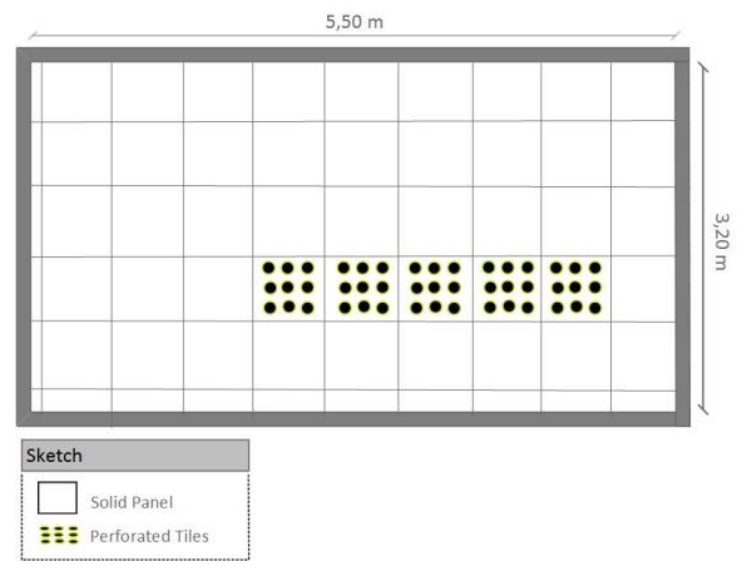

Gambar 131 Denah Raised Floor

Sementara itu untuk perancangan cable tray yang digunakan adalah jenis wire basket berbahan alumunium yang memilki dimensi lebar dan tinggi $20 \times 10 \mathrm{~cm}$. Sedangkan dalam instalasinya hanya menggunakan pemasangan under floor yang terdiri dari 2 cable tray yaitu cable tray untuk kabel listrik dan cable tray untuk kabel data. Menurut ANSI/TIA-569-B, untuk menghindari interferensi antara kabel telekomunikasi/data dengan kabel listrik yang mengandung tegangan listrik lebih dari 5 kva harus dipisahkan dengan jarak minimal $61 \mathrm{~cm}$ (24 inch). Pada data center usulan pemisahan antara kedua alur kabel tersebut dilakukan dengan jarak $100 \mathrm{~cm}$. Berikut contoh denahnya yang dapat dilihat pada gambar 14.

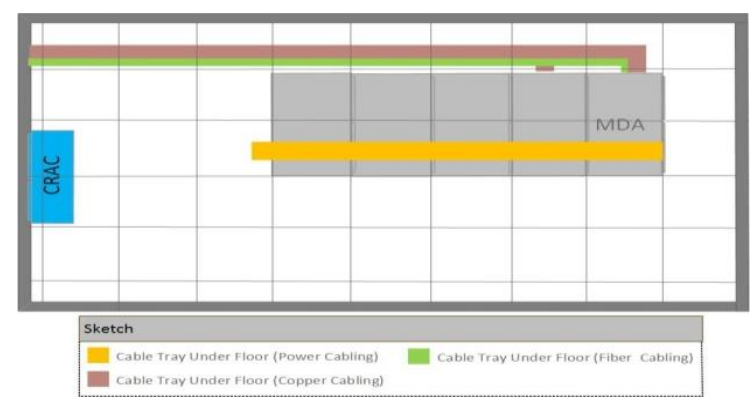

Gambar 14 Desain Cable Tray Listrik dan Data

Desain step tangga bertujuan untuk memudahkan orang masuk kedalam ruangan yang telah dipasang raised floor. Selain step tangga yang biasa digunakan adalah ramp. Pada desain usulan tidak menggunakan ramp karena terlalu menghabiskan space pada computer room. Step tangga dibuat dengan konstruksi rangka besi siku, dan di finishing menggunakan rubber anti slip. Gambar 15 menunjukkan dimensi penggunaan step tangga pada computer room.

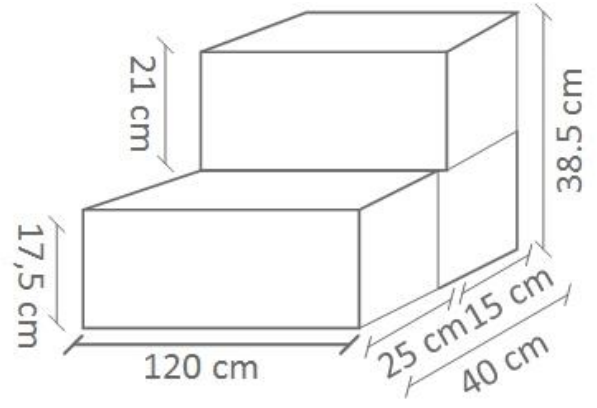

Gambar 15 Desain Step Tangga

\section{A.4 Pengaturan Peralatan}

Pengaturan peralatan merupakan aliran proses utama perancangan yang menggambarkan tata letak peralatan diruang data center dengan ketentuan clearance area pada setiap peralatannya. Berikut contoh dari posisi penempatan infrastruktur peralatan data center usulan yang dapat dilihat pada gambar 16. Pada computer room terdapat komponen-komponen pengaman secara fisik seperti cctv (closed-circuit television) dan access door. Penggunaan cctv sebanyak dua unit yang terletak pada pojok atas ruangan sedangkan access door hanya digunakan untuk computer room. Ukuran tinggi dan lebar pintu masuk data center serta computer room adalah 2,13 x 1,20 meter, semua pintu dan partisi ruangan menggunakan bahan tahan api. Di ruang operation center terdapat beberapa meja dan komputer untuk monitoring traffic jaringan [5].

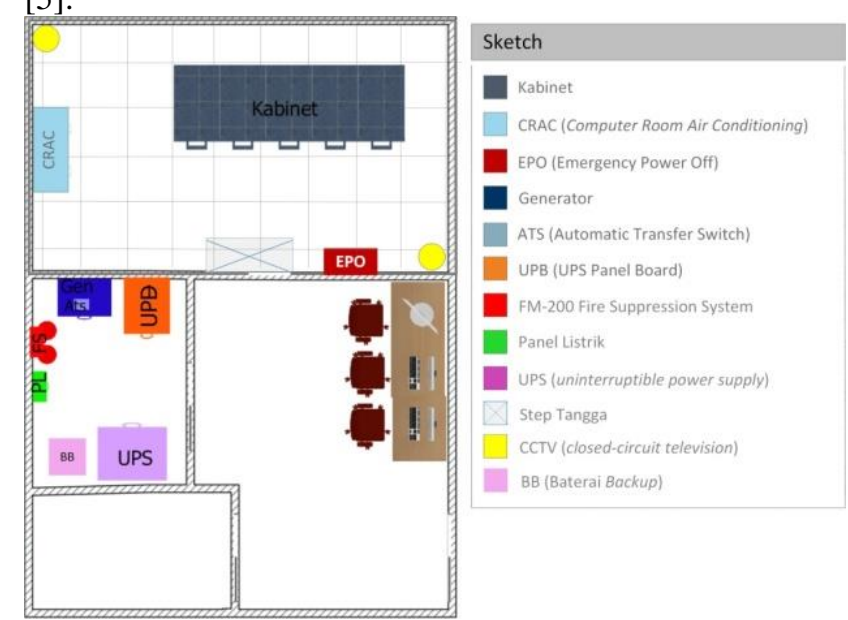

Gambar 16 Desain Tata Letak Peralatan di Data Center

\section{A.5 Pelabelan}

Pelabelan mengikuti standard ANSI/TIA/EIA-606-A yang terdiri dari pelabelan kabinet, patch panel dan pengkabelan. Sebelum menjelaskan tata cara pelabelan maka harus dilampirkan terlebih dahulu posisi kabinet pada raised floor yang terlihat pada Gambar 17. 


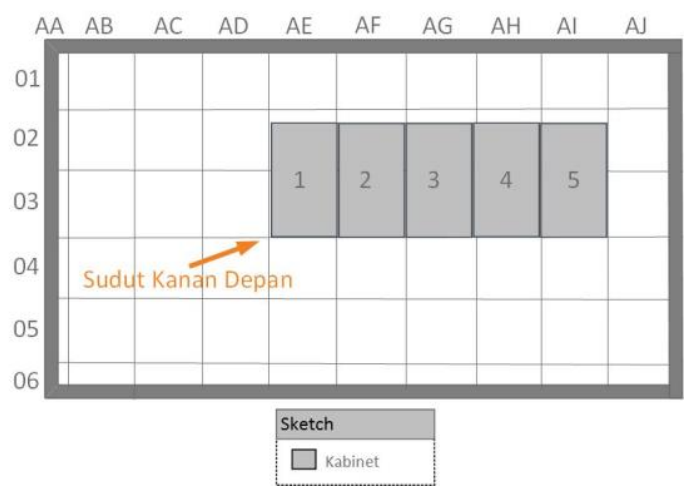

Gambar 17 Posisi Kabinet dan Identifikasi Ubin

\section{A.5.1 Pelabelan rack dan cabinet}

Semua rack dan kabinet harus diberi label dibagian depan dan belakang. Pelabelan terdiri dari dua huruf dan dua digit angka untuk mengidentifikasi setiap ubin lantai pada raised floor. Pada sumbu koordinat $\mathrm{x}$ terdiri dari dua huruf dengan urutan format $\mathrm{AA}, \mathrm{AB}, \mathrm{AC}$ dan seterusnya. Begitu juga dengan sudut koordinat disumbu y terdiri dari dua digit nomor yang diawali 01, 02,03 dan seterusnya.[9]

Jika Kabinet terletak pada lebih dari satu ubin, maka pelabelan kabinet dapat ditentukan dengan menggunakan sudut yang sama pada setiap kabinet (pada desain ini menggunakan sudut kanan depan). Terlihat dari gambar bahwa jika menggunakan sudut kanan depan kabinet maka pelabelannya dapat dijelaskan melalui Tabel 4.

Tabel 4 Pelabelan Kabinet

\begin{tabular}{|l|l|}
\hline Kode Kabinet & Pelabelan \\
\hline 1 & AE03 \\
\hline 2 & AF03 \\
\hline 3 & AG03 \\
\hline 4 & AH03 \\
\hline 5 & AI03 \\
\hline
\end{tabular}

Adapun format baku dalam pelabelan rack dan kabinet adalah,

Keterangan :

\section{XIYı}

Xı : Identifikasi lantai ubin dikoordinat sumbu $\mathrm{X}$

Yı : Identifikasi lantai ubin dikoordinat sumbu y

\section{A.5.2 Pelabelan patch panel}

Pada pelabelan patch panel disini hanya diberikan contoh penggunaan dari format bakunya [10].

Keterangan :

\section{XIYI-AN}

A : menunjukan posisi patch panel pada rack/kabinet

$\mathrm{N}$ : menunjukan port pada patch panel

XıYı : format baku pelabelan kabinet
Pada Gambar 18 diberikan contoh posisi patch panel satu sampai enam yang diberi kode dengan huruf "A" sampai " $F$ ".

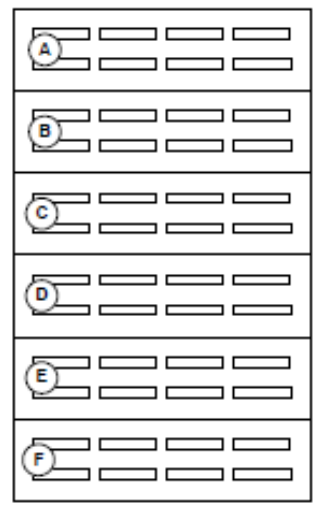

Gambar 18 Identifikasi Susunan Patch Panel

Pada desain ini patch panel terletak pada kabinet AE03, untuk menentukan nomor port keempat di patch panel kedua dilabeli dengan nama AE03-B04. Desain tersebut merupakan pelabelan patch panel didalam satu kabinet. Sedangkan untuk melabeli patch panel antar kabinet maka dapat dilihat pada Gambar 19.

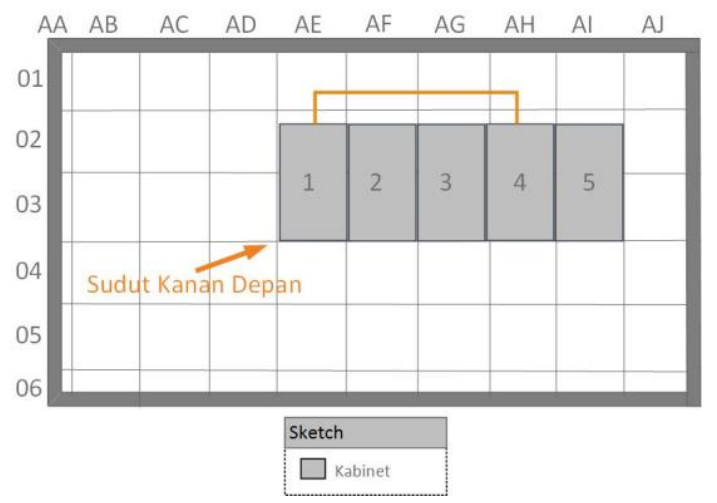

Gambar 19 Konektivitas Patch Panel

Misalnya, untuk memberikan label patch panel pertama 24 port pada kabinet AE03 yang terhubung dengan patch panel kedua 24 port dikabinet AH03 maka dapat dilabeli dengan nama AE03-A to AH03-B Ports 01-24.

\section{A.5.3 Pelabelan Pengkabelan}

Pemberian label pada kabel/patch cord harus menggunakan format baku seperti berikut [10].

Keterangan :

$$
\mathrm{P}_{1} \mathrm{~N} / \mathrm{P}_{2} \mathrm{~N}
$$

P1 : merupakan format gabungan dari pelabelan kabinet dan patch panel pada ujung kabel pertama 
$\mathrm{P}_{2}$ : merupakan format gabungan dari pelabelan kabinet dan patch panel pada ujung kabel kedua

$\mathrm{N}$ : merupakan nomor port terminasi pada kabel

Misalnya, kabel terkoneksi dari patch panel port 1 dikabinet AEO3-A ke patch panel port 1 dikabinet AH03-B, maka dapat dilabeli dengan nama AE03-A01 / AH03-B01 dan pada ujung kabel yang satu lagi dengan nama AH03-B01 / AE03-A01.

\section{B. Perbandingan Data Center Usulan dengan Tierl \\ Dalam rangka mengetahui ketercapaian} desain usulan terhadap empat aspek penilaian TIA tier 1 maka dilakukan pemappingan/perbandingan diantara keduanya. Adapun hasil dari perbandingan tersebut dapat dilihat pada tabel 5 .

Tabel 5. Hasil Perbandingan Data Center Usulan

\begin{tabular}{|l|c|c|}
\hline Aspek Penilaian & $\begin{array}{c}\text { Jumlah } \\
\text { kriteria } \\
\text { wajib }\end{array}$ & $\begin{array}{c}\text { Jumlah } \\
\text { kriteria } \\
\text { terpenuhi }\end{array}$ \\
\hline Arsitektur & 2 & 0 \\
\hline Kelistrikan & 15 & 15 \\
\hline Telekomunikasi & 2 & 2 \\
\hline Mekanik & 3 & 3 \\
\hline Total & $\mathbf{2 2}$ & $\mathbf{2 0}$ \\
\hline
\end{tabular}

\section{Rekomendasi}

Hasil yang diperoleh dari permetaan kondisi saat ini dan usulan data center menggunakan standar TIA Tier 1 terlihat pada tabel 6 .

Tabel 6 Hasil Pemetaan Akhir Data Center

\begin{tabular}{|l|c|c|c|}
\hline Aspek & $\begin{array}{c}\text { Jumlah } \\
\text { kriteria } \\
\text { wajib } \\
\text { (TIA } \\
\text { Tier1) }\end{array}$ & $\begin{array}{c}\text { Jumlah } \\
\text { kriteria } \\
\text { terpenuhi } \\
\text { (Saat ini) }\end{array}$ & $\begin{array}{c}\text { Jumlah } \\
\text { kriteria } \\
\text { terpenuhi } \\
\text { (Usulan) }\end{array}$ \\
\hline Arsitektur & 2 & 0 & 0 \\
\hline Kelistrikan & 15 & 10 & 15 \\
\hline Telekomunikasi & 2 & 0 & 2 \\
\hline Mekanik & 3 & 0 & 3 \\
\hline Total & $\mathbf{2 2}$ & $\mathbf{1 0}$ & $\mathbf{2 0}$ \\
\hline
\end{tabular}

Hal ini menunjukkan bahwa desain/ perancangan yang diusulkan telah mendekati dengan kriteria yang dipersyaratkan oleh standar TIA Tier1 Data Center. Sementara untuk kekurangannya diusulkan Ruang data center harus bisa menahan kapasitas beban lantai minimum 7,2 kPa (150 lbf/sq ft) serta beban lantai hanging 1,2 kPa (25 lbf/sq ft). Pada ruang data center usulan, kriteria ini belum bisa dicapai karena struktur bangunan data center saat ini merupakan struktur bangunan gedung office standar. Maka dari itu untuk memenuhi kriteria ini harus didirikannya bangunan baru dengan memperhatikan kapasitas beban lantai yang telah ditetapkan oleh tier 1. Sebagai pedoman untuk dilakukannya metode uji kapasitas beban lantai maka dapat menggunakan standard telcordia gr-63core.

\section{KESIMPULAN DAN SARAN}

Adapun kesimpulan dan saran yang didapatkan dari hasil penelitian ini yaitu :

A. Kesimpulan

1. pihak Puslitbang XYZ telah mendapatkan dokumentasi secara menyeluruh terhadap infrastruktur data center eksistingnya.

2. pihak Puslitbang XYZ telah mendapatkan gambaran perbandingan data center eksisting dan data center usulan terhadap data center TIA tier 1/

3. pihak Puslitbang XYZ telah mendapatkan rekomendasi dan rancangan desain data center berdasarkan pendekatan TIA tier 1 .

\section{B. Saran}

Sementara itu saran dari penulis merupakan pemberian rekomendasi untuk mencapai tier 2 terhadap desain data center usulan. Adapun rekomendasi tersebut sebagai berikut :

1. Menyediakan lokasi baru untuk data center dengan ukuran besar yang dapat menampung infrastruktur tier 2,

2. Penggunaan lapis dinding interior dengan memasang plywood yang tebalnya tidak kurang dari $16 \mathrm{~mm}(5 / 8)$ dengan perekat serta sekrup setiap $300 \mathrm{~mm}$ (12 inci). Hal ini dilakukan sebagai antisipasi pencegahan minimal terhadap api jika terjadi kebakaran pada data center,

3. Menyediakan ruangan terpisah antara generator dengan UPS \& battery backup dengan nama generator room dan UPS \& baterai room,

4. Melakukan metode uji terhadap lantai bawah dan hanging dengan beban lantai bawah minimum 8,4 kPa (175 lbf / ft2) dan lantai hanging minimum 1,2 kPa (25 lbf / ft2),

5. Mempunyai komponen redundant $\mathrm{N}+1$ terhadap sistem mekanik seperti UPS, generator dan alat pendingin (CRAC) serta sistem telekomunikasi seperti router core, switch core dan switch SAN core harus memiliki komponen redundan,

6. Mempunyai generator dengan kemampuan menahan beban penuh 24 jam non stop,

7. Mempunyai baterai backup dengan kemampuan menahan beban penuh minimal 10 menit,

8. Data center menggunakan Typical Data Center Topology, 
9. Serta mempunyai ketinggian raised floor minimal $45 \mathrm{~cm}$.

\section{DAFTAR PUSTAKA}

[1] Standard, TIA. 2005. Telecommunication Infrastructure Standard For Data Center. USA: TIA-942.

[2] Yulianti, Diah Eka., \& Hafda Bayu Nanda. 2008. Best Practice Perancangan Fasilitas Data Center. Bandung: Institut Teknologi Bandung.

[3] Prayogo, Dimas., dkk. 2013. Evaluasi Kinerja Aplikasi Indeks Pengajaran Dosen Dengan Menggunakan Gap Analisis. Jurnal Teknik Pomits. Surabaya: Institut Teknologi Sepuluh November.

[4] Afrianto, I. and Setiawan, E., 2015. Kajian virtual private network (vpn) sebagai sistem pengamanan data pada jaringan komputer (studi kasus jaringan komputer unikom). Majalah Ilmiah UNIKOM, 12(1).

[5] Komputer, wahana. 2006. Menginstalasi Perangkat Jaringan Komputer . Jakarta: PT Elex Media komputindo.

[6] Team, Biz Diagram. (2014). Gap Analysis. From http://bizdiagram.com/tag/gapanalysis-analysis/. 10 Oktober 2014.

[7] Jalasistema. (2010). Raised Floor/Access Floor. From http://www.jalasistema.com/index.php/produ ct-a-services/raised-floor--access -floor. 10 Februari 2015.

[8] Setiawan, Agus. (2012). Pengertian dan Jenis Server.

From http://www.transiskom.com/2012/09/pengert ian-dan-jenis-server.html. 20 Oktober 2014

[9] Kakus, Lobang. (2009). Pengertian Rack Server. From https://www.scribd.com/doc/24019105/Peng ertian-Rack-Server. 15 December 2014.

[10] Ariqa, Niee. (2013). Fungsi dan Kegunaan Patch cord atau Patch cabel. From http://www.ngulik.org/2013/08/fungsi-dankegunaan-patch-cord.html. 28 Januari 2015. 